\title{
Phenology and productive performance of chamomile in sowing dates and spacing between plants
}

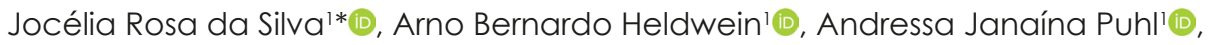

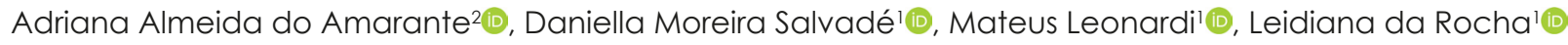

'Federal University of Santa Maria, Santa Maria, Brazil

${ }^{2}$ Federal University of Pelotas, Capão do Leão, Brazil

*Corresponding author, e-mail: joceliarosa.s@gmail.com

\begin{abstract}
The present work has aimed to evaluate phenology and productive performance of chamomile in a subtropical weather region, sown in different dates and spacings in between plants. The experiment took place in Santa Maria - RS with four sowing dates in the year 2017 (18/03, 28/04, 30/06 and 31/08) and seven spacings along plants in rows $(5,10,15,20,25,30$ and $40 \mathrm{~cm})$, spaced $30 \mathrm{~cm}$ between each other. Phenological observations were made every two or three days in two plants per portion while also accounting for the number of nodes in the main stem. The harvest of chamomile floral chapters was performed manually from the beggining of flowering and repeated biweekly until plant maturation. Productivity of dry floral chapters as well as content and productivity of essential oils were evaluated. It was established that sowing dates affect the productivity of dry floral chapters, content and productivity of essential oil from cv. Mandirituba chamomile, with the sowings of March 18th and April 28th presenting the highest values for such variables. Increasing the space between plants from the $10 \mathrm{~cm}$ line to $40 \mathrm{~cm}$ in lines spaced in $30 \mathrm{~cm}$ has shown a linear tendency of decreasing the productivity of dry floral chapters. Spacings between plants did not affect the phenological development of chamomile, however, sowing dates interfered in the thermal time of six evaluated subperiods regarding plastochron and the final number of nodes.
\end{abstract}

Keywords: Chamomilla recutita L., meteorological conditions, medicinal plants, thermal time

\section{Introduction}

The development of formulated drugs and their greater availability to the population facilitated the quick control of infirmities, although the use of medicinal plants is still high, especially due to their economic viability and cultural influence. According to the World Health Organization (2011), nearly 70 to $95 \%$ of the population of developing countries use medicinal plants for primary healthcare. In Brazil, chamomile (Chamomilla recutita L.) is the medicinal plant of greatest economic and social expression, presenting a growing demand (Corrêa Júnior \& Scheffer, 2014). In order to meet this growing demand for chamomile, it is not only necessary to increase the yield of floral chapters but also to increase studies to foster the expansion of cultivation areas while improving quality, which makes research development of paramount importance.

The sowing date is among the factors that cause variation in the productivity of floral chapters and essential oil, linked to the meteorological conditions that occur throughout the development cycle (Salamon, 2007; Mohammad et al., 2010). The choice of the best sowing date is an efficient management practice that allows the better expression of the productive potential of the crops without increasing production costs, especially for avoiding or minimizing the risks of thermal and water stress damage to plants or that these coincide with the most critical subperiods of the crop cycle. The meteorological variables also influence the phenology of plants, with the knowledge of how this relationship occurs constituting an important instrument to minimize crop positioning errors and to estimate the variability of the duration of cycles, according to the environmental conditions. In the state of Rio Grande do Sul, chamomile has occupied an important space, especially in small properties, as an option to diversify crops that generate extra income for rural 
producers. However, there are no recommendations for regions of humid subtropical climate, such as the central region of the state of Rio Grande do Sul, regarding the best sowing date for chamomile plants to present their maximum productive potential.

Chamomile cultivation in planting rows, although demanding more manpower than through broadcast sowing, facilitates the control of weeds and has provided superior yields (Corrêa Júnior et al., 1994). However, there is a scarcity of available scientific information to support a technical recommendation regarding the correct spacing between plants in chamomile sowing in rows, in subtropical regions, aiming at a maximum production of floral chapters. Neither are found results that describe the phenological development of chamomile plants in relation to the spacing between plants and sowing times.

Aiming at the amplification of the area cultivated with chamomile in the central region of Rio Grande do Sul, especially as an option for family agriculture, this study aimed to evaluate the phenology and productive performance of chamomile sown on different dates and spacings between plants.

\section{Material and Methods}

The experiment was conducted in the experimental field of the Phytotechny Department of the Federal University of Santa Maria, RS (latitude: $29^{\circ} 43^{\prime} \mathrm{S}$, longitude: $53^{\circ} 43^{\prime} \mathrm{W}$, and elevation of $95 \mathrm{~m}$ ). According to the classification by Köppen and the centennial series of meteorological data, the climate of the region that comprises the city of Santa Maria is classified as Cfatype, described as a humid subtropical climate with hot summers and without a defined dry season. The soil of the place is a Ultisol (Argissolo Vermelho distrófico típico), belonging to the São Pedro mapping unit (Streck et al., 2008).

The experiment was organized in a completely randomized block design, in a bifactorial scheme, testing the factors sowing date and spacing between plants. Sowing was performed on March 18, April 28, June 30, July 28, and August 31, 2017, with seeds of the chamomile $\mathrm{cv}$. Mandirituba, with seven spacings $(5,10$, $15,20,25,30$, and $40 \mathrm{~cm}$ ) between plants in the row and $30 \mathrm{~cm}$ between planting rows, totaling densities of $66,33,22,16,13,11$, and 8 plants $m^{-2}$, respectively. Each sowing date comprised 28 experimental units, using 4 replications for each of the seven spacings between plants. Each experimental unit, with dimensions of $3 \times 3$ $\mathrm{m}$, was composed of 10 planting rows, forming a total area of $9.0 \mathrm{~m}^{2}$ and a useful area of $4 \mathrm{~m}^{2}$. Throughout the cycle, whenever necessary, the supplementary irrigation was performed through dripping, to avoid the exposure of the plants to water deficit. Approximately 15 days after emergence, the thinning of the plants in excess was performed to obtain the spacing between plants defined by each treatment.

The phenological observations were performed three times a week, in two plants per experimental unit, using the phenological scale proposed by Pirzad et al. (2010), proceeding to the counting of the number of nodes (NN) in the main stem of each plant, considering only the leaves with length longer than $2 \mathrm{~cm}$. The final number of nodes (NFN) was determined by counting the maximum number of nodes that the plant emitted in the main stem until harvest. Furthermore, the stages of emergence- EM, four fully developed leaves - V4, beginning of the reproductive stage - IR (when it is possible to visualize the reproductive structure of the chamomile plant), beginning of flowering - IF (5\% of the chapters with open flowers), full bloom - PF (50\% of open chapters), and physiological maturation - MAT $195 \%$ of the inflorescences with brown coloring) were observed.

Each subperiod between stages was computed as number of days and as a thermal time for each plant, in a daily scale (STd, ${ }^{\circ} \mathrm{C}$ day) and, according to the phenological data obtained by the field observations, the accumulated thermal time was calculated for each subperiod of development and for the entire crop cycle. The calculation of the daily thermal time (STd, ${ }^{\circ} \mathrm{C}$ day) was performed according to Arnold (1960): STd $=($ Tmed - Tb)* 1 day (1). The mean air temperature (Tmed, ${ }^{\circ} \mathrm{C}$ ) was calculated from the arithmetic mean between the maximum and minimum daily air temperatures, and $\mathrm{Tb}$ is the basal temperature for leaf emission, which in the chamomile crop is $6.5^{\circ} \mathrm{C}$ (Mohammad, 2011). The calculation of the accumulated thermal time (STa, ${ }^{\circ} \mathrm{C}$ day) was performed by summing the STd values for each subperiod and for the entire cycle, from the emergence of the plants until their physiological maturation (STa $=\Sigma$ STd). From the accumulated thermal time, the estimation of the plastochron index was performed through simple linear regression between the NN and the STa, with the plastochron being the inverse of the angular coefficient of this linear regression (Streck et al., 2005).

The harvest of chamomile floral chapters was manually performed from the IF stage, being repeated biweekly until the MAT stage of the plants, in $0.6 \mathrm{~m}^{2}$ of each experimental unit. After harvest, the floral chapters were weighed in a precision balance with $0.001 \mathrm{~g}$ precision, packed, and stored in a freezer at $-10{ }^{\circ} \mathrm{C}$. For the determination of the chamomile yield and its 
essential oil, all samples collected in the harvest period, in each experimental unit, were mixed for the formation of a single sample per experimental unit. Approximately $50 \mathrm{~g}$ of the fresh mass of floral chapters per experimental unit was used for the extraction of the essential oil, and the remainder of the sample was packed in paper bags in dried in a forced-air circulation oven at $60^{\circ} \mathrm{C}$ until reaching constant weight, and then the weight of the dry mass was registered.

The yield of each experimental unit was obtained by the dry mass of floral chapters, summed to the fresh mass used for the extraction of the essential oil multiplied by the ratio between the dry and fresh mass, that is, the fresh mass used for the oil extraction was transformed into dry mass, after moisture determination in each sample that underwent drying.

The determination of the essential oil content in the 140 samples of chamomile floral chapters was performed by the process of steam distillation, using a graduated Clevenger apparatus coupled to a 2-liter round bottom flask, heated in a heating mantle for 2.5 hours at approximately $100^{\circ} \mathrm{C}$. The content of essential oil was calculated through the ratio between the mass of essential oil extracted and the mass of the sample from which the oil was extracted already transformed into dry mass. For the calculation of the essential oil yield, the multiplication of the floral chapters yield by the essential oil content was performed.

The data of minimum and maximum air temperature, rainfall and incident solar radiation were obtained from an automatic weather station belonging to the National Institute of Meteorology (INMET), located at $90 \mathrm{~m}$ from the experiment.

The normality of errors of the data was tested by the Shapiro Wilk test, and the homogeneity of variances was tested by Bartlett's test, both performed in the Action $\AA^{8} 2.5$ software. In order to meet the assumptions of the mathematic model, the Box-Cox methodology was used for the adequate transformation of the data, whenever necessary. The means of the transformed variables were presented in the results with the original values. The data were subjected to analysis of variance by the F-test at a $5 \%$ level of probability, with the aid of the Sisvar ${ }^{\circledR}$ software (Ferreira, 2011), and when presenting significance, the means of the qualitative variables were compared by the Scott-Knott test, whereas the quantitative variables were subjected to regression analysis. The statistical analysis employed for the number of days and thermal time variables of the chamomile development subperiods consisted of the calculation of the mean, standard deviation (SD), and coefficient of variation (CV).

\section{Results and Discussion}

The five sowing dates exposed the chamomile to different environmental conditions throughout the development cycle, especially regarding air temperature, incident solar radiation and rainfall (Figure 1), which are the most limiting meteorological factors for the expression of vegetal production. These distinct conditions aided in the better understanding of the phenological and productive response of chamomile to meteorological conditions.

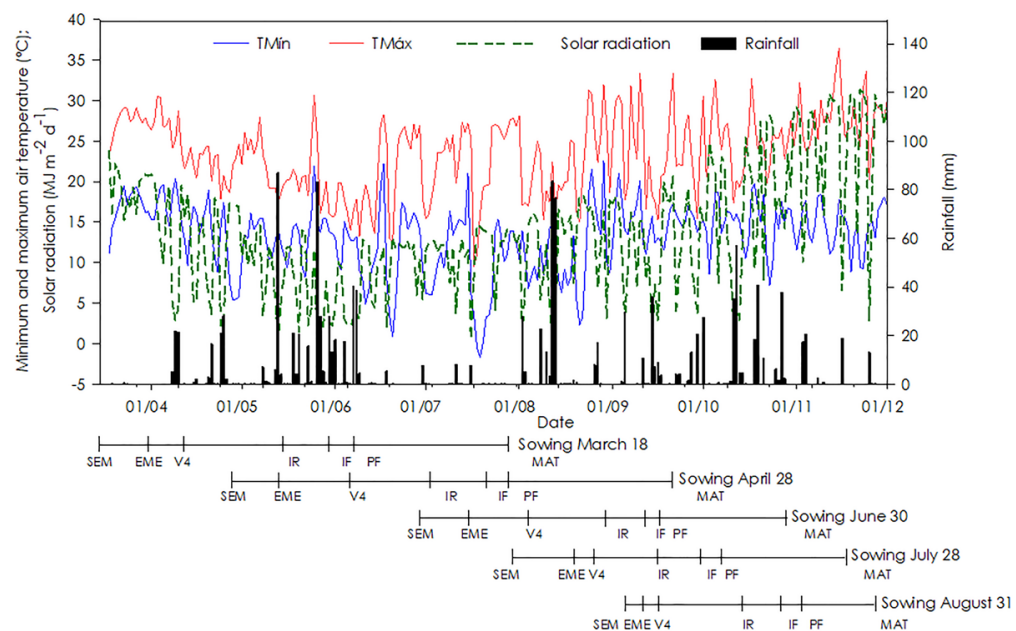

Figure 1. Minimum (TMin, ${ }^{\circ} \mathrm{C}$ ) and maximum daily air temperature (TMax, ${ }^{\circ} \mathrm{C}$ ), incident solar radiation on the surface $\left(\mathrm{MJ} \mathrm{m} \mathrm{m}^{-2} \mathrm{day}^{-1}\right)$, and rainfall $(\mathrm{mm})$ in the period from March 18 to November 31, 2017, and cycle of the chamomile (Chamomilla recutita L.) sown on different dates, in Santa Maria - RS. (SEM = sowing; $E M E=$ emergence; $V 4=$ four fully developed leaves; $I R=$ visualization of the reproductive structure of chamomile; $I F=$ beginning of flowering; $\mathrm{PF}=$ full bloom; $M A T=$ physiological maturation) 
Air temperature varied during the cycle of the plants for all sowing dates, but only in 4 days was the air temperature lower than the Tb of chamomile, inferring a null development in these four days. There were frosts during the vegetative stage of the plants sown in April, June, and July, and in the reproductive stage of those sown in March, April, and June, with no damage being verified in the plants after the occurrence. Damage in chamomile plants caused by frosts was also not found by Mapeli et al. (2005), which confirms the good tolerance of this species to cold, even in the reproductive period. Maximum air temperatures above $30^{\circ} \mathrm{C}$, which are stressful for chamomile (Dalla Costa, 2001), occurred in the vegetative and reproductive stages of all sowing dates, although their frequency increased in later sowing dates, mainly implying in the shorter duration of the plant cycle.

In the month of May, there was a high rainfall accumulation (314.6 mm), $247 \%$ higher than the climatological normal of this month. In this rainy period, days $13(87 \mathrm{~mm})$ and 26 of May $(83 \mathrm{~mm})$ are highlighted, in which the plants of the March sowing were in the V4IF subperiod, and those sown in April were in the SEM-V4 subperiod, which may have increased the duration of these subperiods.

For the phenological and productive variables studied, there was no interaction between the sowing date and the spacing between plants, which may indicate a standard plant spacing for all sowing dates. Only the floral chapters yield varied with the tested spacing, inferring that with an adequate plant population there is a better use of available resources, resulting in higher yield. However, not all phenological and productive variables presented differences regarding the sowing date, which demonstrates the influence of meteorological elements on the phenology and yield of chamomile.

The total duration of the development cycle and the SEM-EME, EME-V4, V4-IR, IR-IF, IF-PF, PF-MAT, and SEMMAT subperiods varied between sowing dates, regardless of whether the time was accounted for in days or as a thermal time (Figure 2).

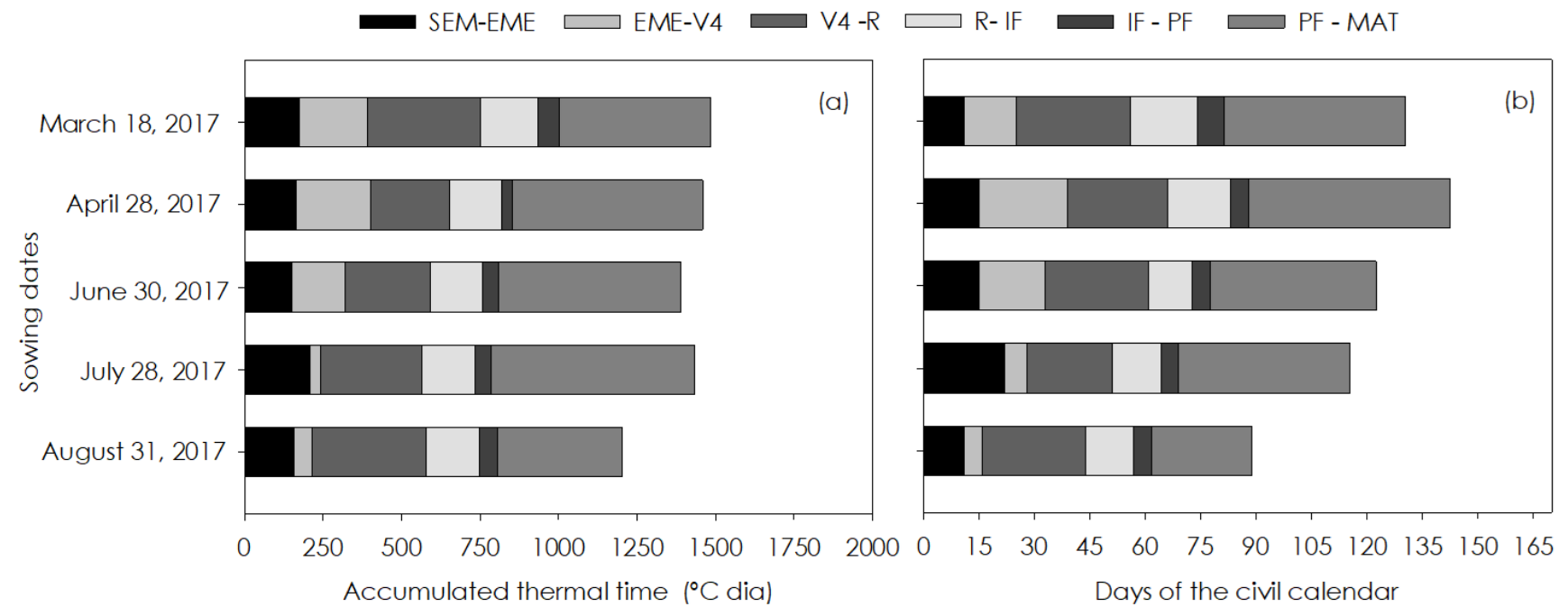

Figure 2. Duration of the development subperiods from sowing to emergence (SEM-EM), from emergence to four developed nodes (EM-V4), from four developed nodes to the beginning of the reproductive stage (V4-IR), from the beginning of the reproductive stage to the beginning of flowering (IR-IF), from the beginning of flowering to full bloom (IF-PF), and from full bloom to physiological maturation (PF-MAT) of chamomile (Chamomilla recutita L.), as a function of the calculated thermal time (A) and the number of days (B) for different sowing dates.

When the time was represented as a thermal time, the duration of the SEM-EME, IR-IF, IF-PF, and PFMAT subperiods and also of the total plant cycle (SEMMAT) presented less variation than in the accounting in days (Table 1). However, for the EM-V4 and V4-IR subperiods, the thermal time presented less variation, ratifying that besides the air temperature, other factors, such as the cumulative rainfall, may have affected plant development.

The subperiod with the highest $C V$ was that of crop establishment (EME-V4), with a contrast from 5 to 24 days from the August sowing to that performed in May (Table 1), which may be associated with the meteorological conditions in this subperiod. For the plants sown in July, the large thermal variation between August 21 (Tmin = $\left.2.3^{\circ} \mathrm{C}\right)$ and August $24\left(\operatorname{Tmax}=31.3^{\circ} \mathrm{C}\right)$, but under optimal availability of solar radiation, possibly stimulated leaf emission due to a high photosynthesis rate, associated to a wide thermal amplitude (mean of $13.7^{\circ} \mathrm{C}$ ), and growing air temperature. According to Von Hertwig (1991), some medicinal plants are quite demanding in a certain thermal amplitude, observing greater growth associated 
with larger thermal amplitudes. The plants of the March sowing had a longer EME-V4 subperiod (24 days), possibly due to the high rainfall $(355 \mathrm{~mm}$ ), which caused water stress and lower availability of solar radiation to the plants. This greater prolongation of the EME-V4 subperiod allows inferring that the low initial growth rate of the chamomile sown in March and April also impairs its ability for initial competition with weeds if there is a lower thermal time, and possibly the availability of solar radiation was not adequate to promote quick development of the plants once they emerged. Therefore, the sowings from March to April, in years that present higher rainfall that the Climatological Normal for this period (El Niño), may damage chamomile plants just when a rapid initial plant growth is desired.

A longer vegetative stage was observed in the plants from the wwrst sowing date, probably due to the lower thermal time caused by frequent rain, which also hardened the establishment process of the plants sown in April. The knowledge of the occurrence moment of the V4-IR subperiod is important for the crop management of chamomile since nitrogen fertilization via topdressing is indicated at this moment (Amaral et al., 2008), besides irrigation management, considering that it is in this subperiod that the crop develops its productive potential (Singh et al., 2011).

Table 1. Mean, standard deviation (SD, day or ${ }^{\circ} \mathrm{C}$ day), and coefficient of variation (CV, \%) of the duration of development subperiods from sowing to emergence (SEM-EME), from emergence to four developed nodes (EME-V4), from four developed nodes to the beginning of the reproductive stage (V4-IR), from the beginning of the reproductive stage to the beginning of flowering (IR-IF), from the beginning of flowering to full bloom (IF-PF), from full bloom to physiological maturation (PF-MAT), and of the full cycle (SEM-MAT) of chamomile (Chamomilla recutita L.) as a function of the thermal time methodology (STa, ${ }^{\circ} \mathrm{C}$ day) and the number of days of the civil calendar (Day).

\begin{tabular}{|c|c|c|c|c|c|c|c|c|c|c|c|c|c|c|}
\hline & \multicolumn{2}{|c|}{ SEM-EME } & \multicolumn{2}{|c|}{ EME-V4 } & \multicolumn{2}{|c|}{ V4-IR } & \multicolumn{2}{|c|}{ IR-IF } & \multicolumn{2}{|c|}{ IF-PF } & \multicolumn{2}{|c|}{ PF-MAT } & \multicolumn{2}{|r|}{ SEM-MAT } \\
\hline & Day & STa & Day & STa & Day & STa & Day & STa & Day & STa & Day & STa & Day & STa \\
\hline Mean & 14.8 & 170.4 & 13.4 & 143.3 & 27.4 & 313.7 & 14.7 & 171.2 & 5.1 & 52.1 & 44.5 & 542.7 & 120.5 & 1392.6 \\
\hline SD & 4.5 & 21.9 & 8.1 & 92.6 & 2.9 & 51.9 & 2.8 & 7.4 & 1.1 & 11.6 & 10.3 & 101.7 & 20.1 & 111.8 \\
\hline CV & 30.4 & 12.9 & 60.1 & 64.6 & 10.5 & 16.5 & 19.2 & 4.3 & 22.3 & 21.9 & 23.1 & 18.7 & 16.7 & 8.0 \\
\hline
\end{tabular}

The IR-IF subperiod presented the lowest thermal time variation, being the most influenced by the thermal condition since the difference from the March sowing to that performed in April was only $18^{\circ} \mathrm{C}$ day. Regarding the accounting of this subperiod in days, the difference was 27 days lower for the plants of the August sowing compared to those of April. Knowing the duration of the IF-PF subperiod is important since the content and composition of the essential oil present variation with the development stages of the flower. According to Amaral et al. (2014), the highest yield of the essential oil is found in the harvest of chapters performed in the first days of flowering, with a decrease occurring in subsequent harvests.

The PF-MAT subperiod is the one with the highest production of floral chapters, with the harvest point being determined when most of these are open (Biasi \& Deschamps, 2009). With a longer duration of the PF-MAT subperiod, the plants emitted flowers for a longer time, with greater production of chamomile floral chapters, although also resulting in an undesirable higher number of harvest pickings. According to Amaral et al. (2014), the most appropriate 'harvest age' of the chamomile cv. Mandirituba, to obtain a greater dry mass of chapters, is at 106 DAE, between PF and MAT. However, if this criterion were adopted in the present work, the harvest would not occur within the proper moment in four out of five sowing dates (Figure 2B). The knowledge of the necessary thermal time for full bloom allows the producer to adopt a better harvest planning, performing it when there is a greater production of floral chapters, which allows to schedule the hiring of laborers if necessary, whereas the criterion of DAE accounting show to be inadequate.

The duration of the full cycle (SEM-MAT) was also better described by the thermal time. This result demonstrates that chamomile is strongly influenced by thermal availability and that air temperature may be a limiting factor for its development. The shortening of the cycle of the plants sown in August, especially the reduction of the period of flower emission and flowering, may be related to the thermal stress to which the plants were exposed. The cycle of the plants sown in August was shortened by the occurrence of several days with the air temperature above $30^{\circ} \mathrm{C}$. According to Galambosi \& Szebenl (1992), the most adequate temperature for chamomile is from 10 to $21^{\circ} \mathrm{C}$ in all development phases of the plant; in high temperatures, from 28 to $32^{\circ} \mathrm{C}$, there is a shortening of the anthesis period.

For the subperiod that comprises EME-V4 and V4IR, the thermal time methodology demonstrated greater variation than the counting of days. The thermal time method presents a critical point, which is the assumption of constant linearity between air temperature and plant development and growth. In this perspective, Streck (2002) affirms that such an assumption is not totally realistic from the biological perspective since the response of biological 
processes to air temperature is linear, in a thermal range between the basal lower and upper temperatures. However, even with these limitations, the thermal demand method is more efficient when compared with that of the number of days, considering that plant development does not occur by the accumulation of days, but rather due to the interaction of several factors that allow the development of the crop, favoring its metabolism, photosynthesis, cell turgor maintenance, and nutrition, among other factors. All these functions or processes shall be provided in a higher or lower degree according to the environmental conditions, with solar radiation, air temperature, and water availability being the factors of greater influence.
The linear regressions between the NN and thermal time presented values of coefficient of determination $\left(R^{2}\right)$ above 0.97 , ratifying that the air temperature is the main meteorological element that influences the emission of chamomile nodes (Figure 3). The plastochron and NFN of chamomile varied according to the sowing date, which indicates that these variables were affected by the environment, with plastochron increase and NFN reduction trend with the delay in sowing. However, it is verified that at least until the plant reaches the V4 stage, the thermal time need per node emission is higher in the first two sowing dates, and the functions obtained for the first three dates do not describe this ontogeny (Figure 3), with more than $250{ }^{\circ} \mathrm{C}$ day being necessary for the
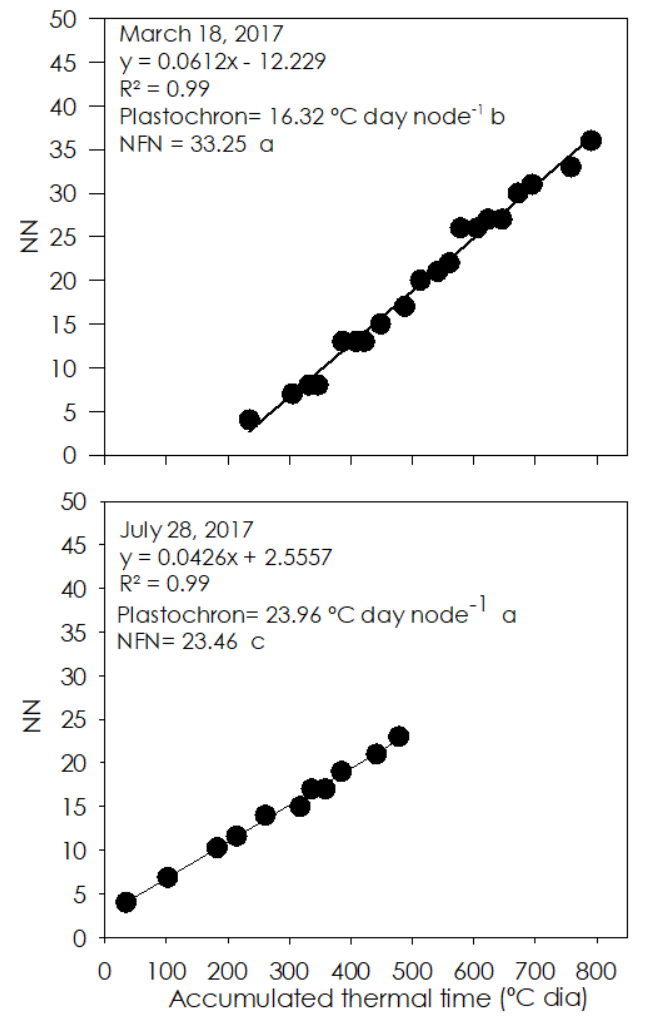

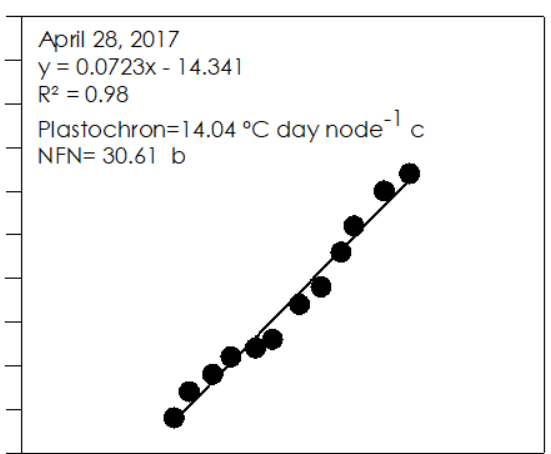

August 31, 2017

$y=0.0419 x-0.0969$

$R^{2}=0.99$

Plastochron $=23.86^{\circ} \mathrm{C}$ day node ${ }^{-1} \mathrm{a}$ $\mathrm{NFN}=23.45 \mathrm{C}$

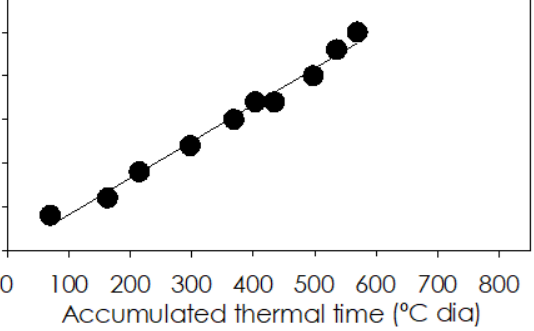

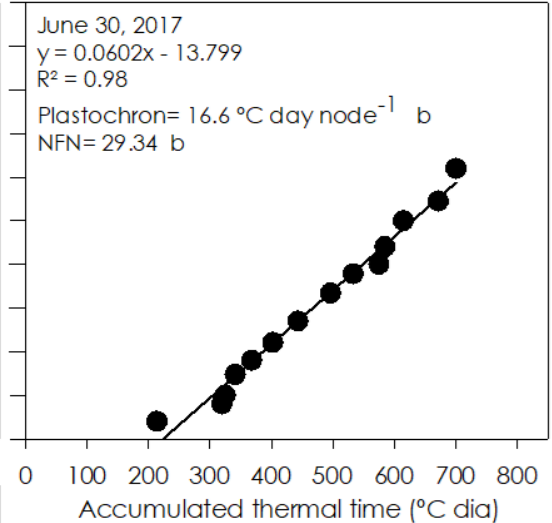

Accumulated thermal time $\left({ }^{\circ} \mathrm{C}\right.$ dia)

Figure 3. Linear regression between the number of nodes (NN) and accumulated thermal time for the determination of the plastochron and the final number of nodes of chamomile plants (Chamomilla recutita L.) sown on March 18 (A), April 2018 (B), June 30 (C), July 28 (D), and August 31, 2017 (E). Means followed by different letters in the plastochron and NFN variables differ significantly from each other by the Scott-Knott test ( $p \leq 0.05)$

emission of the first four nodes (Figure 2). For the last two sowing dates, July 28 and August 31, 2017, the same did occur since the linear coefficient of the respective models presented a trend to zero (Figures 3D and 3E).

On all sowing dates, NN stabilization occurred in the IR-IF subperiod. The NFN is a variable that indirectly explains the growth and responses of the crop since the higher is its value, the greater will be the expansion of the shoot part and leaf area, resulting in greater canopy closure. This greater canopy closure between rows is necessary to reduce the competition by weeds and protect the soil against erosion. The higher NFN value for the March sowing infers greater development and growth of plants, indicating the influence of the different sowing dates and environmental conditions on this variable. A possible determining factor in the decrease of the NFN in the second and third sowing date, in relation to the first one, was the occurrence of frosts, which may have induced the plant to decrease its development and advance the reproductive cycle, as a natural adaptation for the perpetuation of the species. As for the fourth and fifth sowing dates, the high air temperatures may have 
caused a lower node emission due to the acceleration of the cycle.

As well as chamomile, melon (Streck et al. 2005) and soybean (Martins et al., 2011) also exhibited plastochron variation between different sowing dates. However, a variation of $9.82{ }^{\circ} \mathrm{C}$ day is considered significant, especially if the interest is in the use of predictability models that associate the number of nodes to other events that occur in the plant (Streck et al., 2005) and management practices. The difference verified in the plastochron, for the different sowing times, can be explained by the fact that other factors can influence the response of the plant to thermal accumulation, especially during plant establishment, when they provide environmental conditions more or less adequate to plant development. The plastochron increase with the delay in sowing may constitute a response to the photoperiod since the increase of the development rate under a growing photoperiod is a typical response of long-day plants, and chamomile can be induced to the reproductive stage with only eight hours of photoperiod (Salamon, 2007). Franz et al. (1986), studying chamomile under photoperiods of 8,13 , and 18 hours per 24-hour cycle, concluded that this species is responsive to the stretching of the photoperiod, with better performance in terms of floral chapters yield and essential oil content observed in the 18-hour photoperiod.

The maximum floral chapters yield was obtained with the sowing performed on April 28, not differing from the March sowing (Table 2). With the delay in sowing for June and July, there was a reduction of more than $51 \%$ in the yield of dry mass chapters obtained in April. As for the sowing performed in August, the reduction was even more expressive, being $88 \%$ lower than the yield for April. The yields of dried floral chapters for the March and April sowings are superior to those values obtained by Santos ef al. (2015) and Roza et al. (2016) with the sowing performed in May, both in São José dos Pinhais - PR (451 and 615 $\mathrm{kg} \mathrm{ha}^{-1}$, respectively). The values are also superior to the yield found by Nalepa \& Carvalho (2007), with the sowing performed in March in the municipality of Campo Magro - PR $\left(471.8 \mathrm{~kg} \mathrm{ha}^{-1}\right)$. These results demonstrate that the chamomile sowing in Santa Maria exhibits a commercial production potential and may result in superior yields to those found by some authors in the state of Paraná, which presents the largest chamomile production area in Brazil (Corrêa Júnior \& Scheffer, 2014).

The higher yields obtained in the sowings performed in March and April can be associated to the milder air temperature, especially at the plant flowering
Table 2. Yield of dried floral chapters $\left(\mathrm{kg} \mathrm{ha}^{-1}\right)$, essential oil content (\%), and essential oil yield $\left(\mathrm{kg} \mathrm{ha}^{-1}\right)$ of chamomile (Chamomilla recutita L.) sown on different dates in 2017, in Santa Maria, RS

\begin{tabular}{cccc}
\hline $\begin{array}{c}\text { Sowing } \\
\text { date }\end{array}$ & $\begin{array}{c}\text { Dried chapters } \\
\text { yield }\end{array}$ & $\begin{array}{c}\text { Essential oil } \\
\text { content }\end{array}$ & $\begin{array}{c}\text { Essential oil } \\
\text { yield }\end{array}$ \\
\hline March 18 & $823.51 \mathrm{a}^{*}$ & $0.60 \mathrm{a}$ & $4.86 \mathrm{a}$ \\
April 28 & $872.25 \mathrm{a}$ & $0.50 \mathrm{~b}$ & $4.30 \mathrm{a}$ \\
June 20 & $425.41 \mathrm{~b}$ & $0.52 \mathrm{~b}$ & $2.16 \mathrm{~b}$ \\
July 28 & $422.11 \mathrm{~b}$ & $0.49 \mathrm{~b}$ & $2.00 \mathrm{~b}$ \\
August 31 & $100.58 \mathrm{c}$ & $0.52 \mathrm{~b}$ & $0.49 \mathrm{C}$ \\
Mean & 518.99 & 0.53 & 2.76 \\
CV (\%) & 27.5 & 27.2 & 19.4 \\
\hline "Means followed by different letters in the column differ significantly from each other by the Scott- \\
Knott test (ps0.05)
\end{tabular}

phase, with a mean air temperature of $15.5^{\circ} \mathrm{C}$ in the March sowing and $16.5^{\circ} \mathrm{C}$ in that of April (Figure 4A), and with a lower mean of the minimum and maximum air temperature in this subperiod than in the remaining sowing dates. Among the meteorological variables evaluated, the mean air temperature (Figure 4A) and the mean of the maximum air temperature (Figure 4B) exhibited a linear relationship with the yield of dried floral chapters of chamomile, with a decreasing trend with the increase in the mean temperature and mean maximum air temperature. The presented results suggest that the yield of floral chapters tends to zero when the mean of maximum temperatures in the cycle trespasses $30^{\circ} \mathrm{C}$ (Figure 4B).

The closest yield to the crop potential can be achieved with the choice of the best sowing date. With the anticipated sowing (March 18 and April 28), especially due to a longer growth period (Figure 5) with milder air temperatures, which caused less thermal stress, the chamomile plant can express its maximum productive potential. This result corroborates those verified by Johri et al. (1992) and Hadi et al. (2004), who observed a decreasing trend in the floral chapters yield with the delay in sowing, coinciding with higher air temperatures in the reproductive period of the crop. According to Sváb et al. (1967), the weight of chamomile flowers decreases with the increase in the air temperature, with no effect occurring on the composition of the essential oil.

Regarding the studied spacings, the maximum yield of dried floral chapters was verified in the $10 \mathrm{~cm}$ spacing between plants, although with a linear reduction trend with the increase in the plant spacing in the row (Figure 6). In a study performed by Jamshidi (2000), the maximum yield of dried floral chapters of chamomile was also found in a $30 \mathrm{~cm}$ spacing between planting rows and $10 \mathrm{~cm}$ between plants. A similar situation was obtained by Ramos et al. (2004), when studying the effect of plant spacing on chamomile yield, obtaining a linear decrease with the increase in the plant spacing, 
although the result was significantly more contrasting, with a yield change from $1150 \mathrm{~kg} \mathrm{ha}^{-1}$ to $550 \mathrm{~kg} \mathrm{ha}^{-1}$ of dry mass of floral chapters from the spacing of 0.11 to 0.29 $\mathrm{m}$ between plants and $0.27 \mathrm{~m}$ between rows. The fact that the maximum yield was reached with the smallest spacing between plants indicated that there was not enough intraspecific competition to cause a reduction in the yield of floral chapters, in the denser plants. Besides reaching the maximum yield in smaller spacings, the higher plant density resulted in greater soil covering, which can make chamomile more competitive against weeds. Therefore, the adoption of spacings from 5 to $10 \mathrm{~cm}$ between plants, in rows distant $30 \mathrm{~cm}$ from each other (33 to 66 plants $\mathrm{m}^{-2}$ ), is presented as a technical improvement of production, with broad economic advantage for producers since it increases the chapters yield without changing the oil content, and it can also decrease the labor need for hoeing.
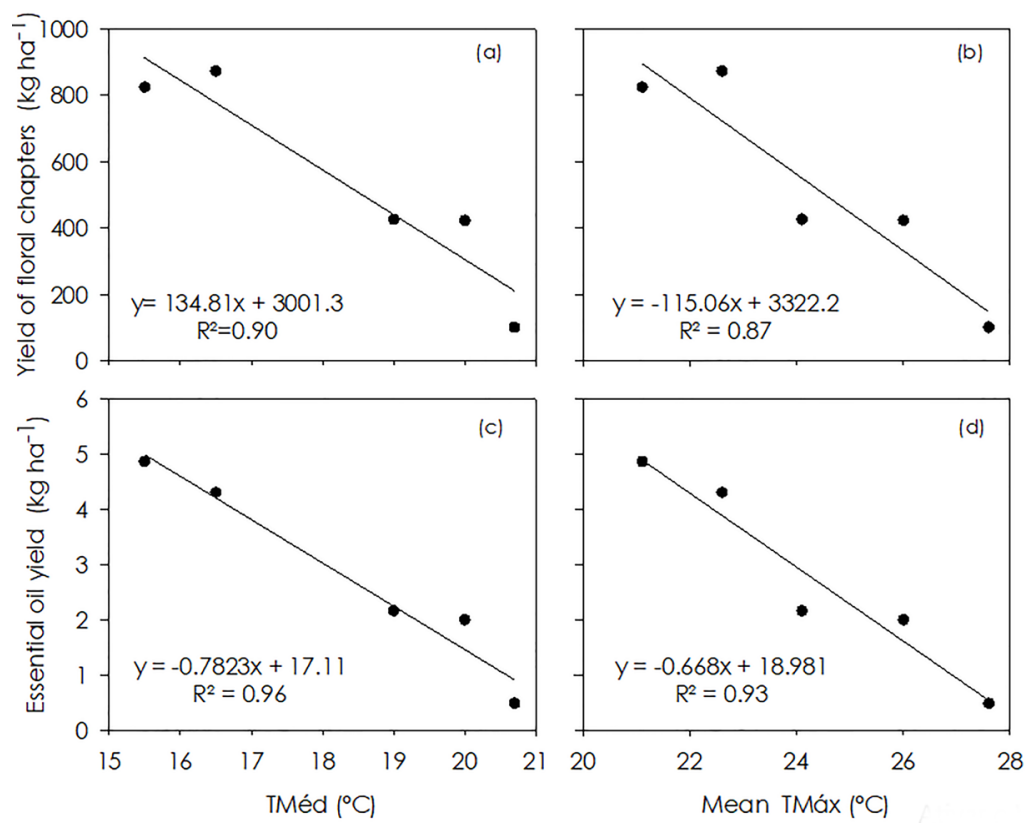

Figure 4. Yield of dried floral chapters in relation to the mean air temperature (A) and in relation to the mean of the maximum air temperature (B), and essential oil yield in relation to the mean air temperature $(C)$ and in relation to the mean of the maximum air temperature (D) occurred in the reproductive stage of chamomile (Chamomilla recutita L.) in 2017, in Santa Maria-RS

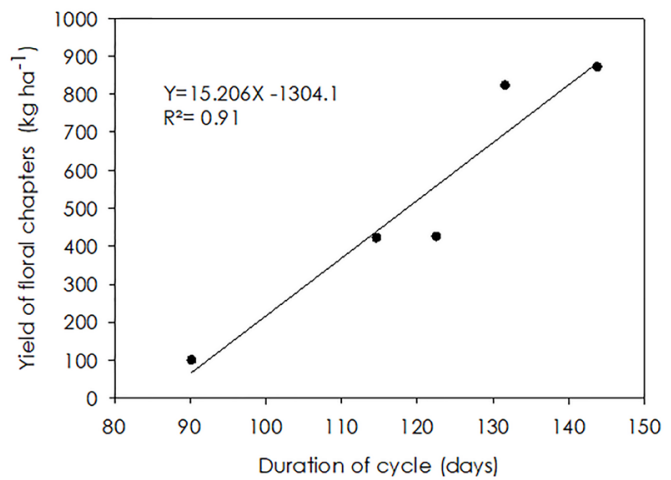

Figure 5. Relationship of the floral chapters yield $\left(\mathrm{kg} \mathrm{ha}^{-1}\right)$ with the duration of the chamomile cycle (days) in Santa Maria-RS

The essential oil content was higher for the sowing performed at the end of March, and the remainder did not differ from each other. However, in all studied dates, values from 22 to $50 \%$ above the minimum required by the Brazilian pharmacopeia (0.4\%) (Corrêa Júnior, 1994) were verified, presenting commercial quality in terms of essential oil content. Such a result may be associated to

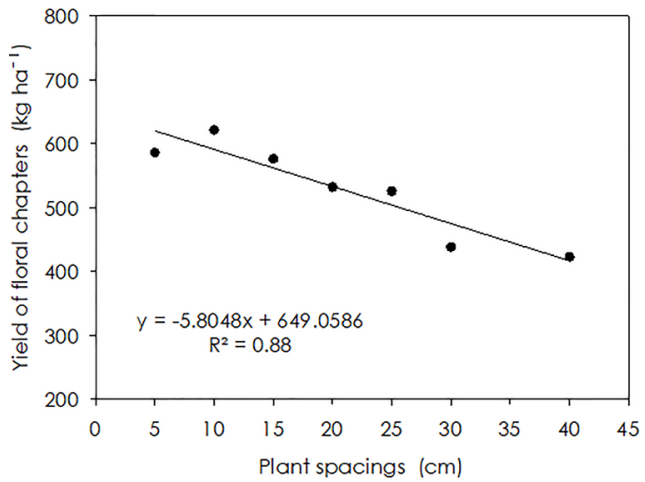

Figure 6. Yield of dried chamomile floral chapters $\left(\mathrm{kg} \mathrm{ha}^{-1}\right)$ in seven different plant spacings in the planting rows in 2017, in Santa Maria-RS

the lower air temperature during the reproductive period, with a maximum temperature peak lower than $30^{\circ} \mathrm{C}$ and lower rainfall also in the reproductive stage, causing the harvests of floral chapters to occur in the most adequate moment, since, according to Amaral et al. (2014), the harvest age of floral chapters of the chamomile $\mathrm{cv}$. Mandirituba affected the essential oil yield. For the cv. 
Mandirituba, the essential oil content can vary from 0.3 to $1.5 \%$, and the main sources of variation are the management techniques and the edaphoclimatic characteristics of the cultivation place (Ramos et al., 2004). Hadi et al. (2004) found decreasing trends in oil concentrations with the delay in chamomile sowing, mainly due to the shorter flower growth period caused by the high air temperatures.

The essential oil content showed no variation with the plant spacing used, rating, on average, $0.53 \%$. This result is in accordance with that found by Ramos et al. (2004) when studying the effect of plant spacing and poultry liter incorporation on the soil, in which the essential oil content of floral chapters did not vary between treatments and was, on average, $0.5 \%$. Such a result is also corroborated by those of Mapeli et al. (2005), who found an equal essential oil content, which did not vary with the tested doses of nitrogen and phosphorus. For Nalepa \& Carvalho (2007), the contents of essential oil of chamomile floral chapters were also not influenced by the fertilization with poultry litter, although being lower, on average, by $0.275 \%$, highlighting that other endogenous and exogenous factors influence the synthesis and concentration of essential oils. Hadi et al. (2004) also did not verify variations in the essential oil content of chamomile subjected to different plant spacings, although verifying a variation with the change in the sowing date. Therefore, it may be inferred that cultivation techniques, such as soil fertilization, population density, and plant spacing, present little or no effect on the chamomile essential oil content. Thus, meteorological conditions, in special air temperature, throughout the cultivation cycle of the plant, and especially in the flowering period, are the main alteration factors in the essential oil content.

The essential oil yield results from the chapters yield and the essential oil content, which underwent a strong influence of the environment. The highest essential oil yields were achieved in the sowings performed in March and April, due to the high yield obtained in the sowing performed and March and April and the higher content of essential oil in the chapters of the plants sown in March. The lowest oil yield was achieved in the sowing performed in August, mainly due to the low chapters yield. These results can be mainly associated with the mean air temperature (Figure 4C) and the mean of the maximum air temperature (Figure 4D) during the chamomile reproductive stage, which showed a strong linear trend with the essential oil yield, with a decreasing trend as the mean temperature and mean of the maximum air temperature increased. In this manner, if the interest of the producer lies in oil extraction, the sowing performed in March, in the central region of Rio Grande do Sul, results in a higher content of essential oil, implying in higher essential oil yield.

The sowings in March and April resulted in a higher yield of dried floral chapters and essential oil, whereas the oil content was higher in the March sowing. The worse results were obtained in the sowing performed in August, with a much lower yield of floral chapters and essential oil compared to the remaining periods evaluated. This behavior is mainly related to the shortening of the crop cycle (Figure 5) when the air temperature is very high, especially in the flowering subperiod (Figure 4A, 4B, 4C, and $4 \mathrm{D}$ ), which may compromise the translocation of photoassimilates to the floral chapters.

Based on these results, it is inferred that chamomile can be cultivated with technical success in areas of a humid subtropical climate, constituting a great socioeconomic potential for producers in the central region of the state of Rio Grande do Sul, once the sowing is preferably performed from mid-March to late April and in high densities, such as 10 to 20 plants per meter, in the planting row. Under these conditions, the crop presents a gross yield that allows good sustainability, considering an average of $R \$ 12.00$ paid to the producer per kilogram of dried floral chapters. If the oil is extracted in a producer cooperative system, the gross income would be even higher, considering that at the current price of the Brazilian market, the commercialization of the essential oil would earn approximately $R \$ 4,600.00$ per kilogram of essential oil paid to the rural producer (Matsushita et al. 2017).

\section{Conclusions}

The spacings between plants did not influence chamomile phenology.

The sowing date interferes with the thermal times of chamomile development subperiods, with longer plastochron and lower number of nodes with the delay in sowing from late April.

The duration of the total chamomile cycle was better described by the thermal time than in days of the civil calendar.

In regions of a humid subtropical climate, the yield of dry floral chapters, as well as the content and yield of chamomile essential oil, are higher when the sowings are performed from mid-March to late April.

The essential oil yield of chamomile chapters decreased with the increase in air temperature in the flowering subperiod.

There is a reduction linear trend in the yield of the 
dried chamomile floral chapters with the increase in the spacing between plants in the row above $10 \mathrm{~cm}$, in rows distanced in $30 \mathrm{~cm}$.

\section{Acknowledgments}

This work was performed with the financial support from the National Council for Scientific and Technological Development (CNPq) and the Coordination for the Improvement of Higher Education Personnel (CAPES).

\section{References}

Amaral, W., Deschamps, C., Favaretto, N., Koeler, H.S., Scheer, A.P., Yamamoto, C. Côcco, L.C. 2008. Desenvolvimento, rendimento e composição de óleo essencial de camomila [Chamomilla recutita (L.) Rauschert] sob adubação orgânica e mineral. Revista Brasileira de Plantas Medicinais 10: 1-8.

Amaral, W., Deschamps, C., Machado, M.P., Koeler, H.S., Scheer, A.P., Côcco, L.C. 2014. Desenvolvimento da camomila, rendimento e qualidade do óleo essencial em diferentes idades de colheita. Revista Brasileira de Plantas Medicinais 16: 237-242.

Arnold, C.Y. 1960. Maximum-minimum temperatures as a basis for computing heat units. Proceedings American Society for Horticultural Science 76: 682-692.

Biasi, L.A., Deschamps, C. 2009. Plantas aromáticas do cultivo à produção de óleo essencial. Layer Studio Gráfico e Editora Ltda, Curitiba, Brazil. 160 p.

Corrêa Júnior, C. 1994. Influência das adubações orgânica e química na produção de camomila [Chamomila recutita (L.) Rauschert] e do seu óleo essencial. 95f. (M.Sc. Thesis) - São Paulo State University Botucatu, Brazil.

Corrêa Júnior, C., Scheffer, M.C. 2014. As plantas medicinais, aromáticas e condimentares e a agricultura familiar. Horticultura Brasileira 32: 376.

Dalla Costa, M.A. 2001. Processo de produção agrícola da cultura da camomila no município de Mandirituba - PR. 69f. (M.Sc. Thesis) - Universidade Federal Paraná, Curitiba, Brazil.

Ferreira, D.F. 2011. Sisvar: um sistema computacional de análise estatística. Ciência e agrotecnologia 35: 10391042.

Franz, C., Müller, E., Pelzmann, H., Hårdh, K., Hälvä, S., Ceylan, A. 1986. Influence of ecological factors on yield and essential oil of camomile (Chamomilla recutita (L.) Rauschert syn, Matricaria chamomilla L.). Acta Horticulturae 188: 157-162.

Galambosi, B., Szebeni, Z. 1992. Experiments on elaborating growing technics for chamomile in Finland. Acta Horticulturae 306: 408-420.

Hadi, M.H.S., Noormohammadi, G., Sinaki, J.M., Khodabandeh, N., Yasa, N., Darzi, M.T. 2004. Effects of planting time and plant density on flower yield and active substance of Chamomile (Matricaria chamomilla L.). Proceedings of the 4th International Crop Science Congress, Brisbane, Australia.

Jamshidi, K. 2000. Effects of row spacing and plant density on quantitative aspects of chamomile flower. Iranian Journal of Agriculture Science 31: 203-210.

Johri, A.K., Srivastava, L.J., Singh, J.M., Rana, R.C. 1992. Effect of time of planting and level of nitrogen on flower and oil yields of German chamomile (Matricaria-recutita). Indian Journal Agronomy 37: 302-304.

Mapeli, N.C., Vieira, M.C., Heredia, Z., Néstor, A., Siqueira, J.M. 2005. Produção de biomassa e de óleo essencial dos capítulos florais da camomila em função de nitrogênio e fósforo. Horticultura Brasileira 23: 32-37.

Martins, J.D., Radons, S.Z., Streck, N.A., Knies, A.E., Carlesso, R. 2011 . Plastocrono e número final de nós de cultivares de soja em função da época de semeadura. Ciência Rural 41: 954-959.

Matsushita, M.S., Deschamps, C., Corrêa Júnior, C. 2017. Análise socioeconômica da produção de capítulos florais e óleo essencial de cultivares de camomila. IGepec 21: 122-130.

Mohammad, R., Hamid, S., An, A., Norbert D.K., Patrick, V.D. 2010. Effects of planting date and seedling age on agro-morphological characteristics,essential oil content and composition of German chamomile (Matricaria chamomilla L.) grown in Belgium. Industrial Crops and Products 3: 145-152.

Mohammad, S.M. 2011 . Study on Cammomile (Matricaria chamomilla L.) usage and farming. Advances in Environmental Biology 5: 1446-1453.

Nalepa, T., Carvalho, R.I.N. 2007. Produção de biomassa e rendimento de óleo essencial em camomila cultivada com diferentes doses de cama-de-aviário. Scientia Agraria 8: 161-167.

Pirzad, A., Shakiba, M.R., Zehtab-Salmasi, S., Mohammadi, S.A., Darvishzadeh, R., Hassani, A. 2010. Phenology of German chamomile and its changes under different irrigation regimes and plant densities. Notulae Scientia Biologicae 2: 43-48.

Ramos, M.B.M., Vieira, M.C., Zárate, N.A.H., Siqueira, J.M., Ziminiani, M.G. 2004. Produção de capítulos florais da camomila em função de populações de plantas e da incorporação ao solo de cama-de-aviário. Horticultura Brasileira 22: 566-572.

Roza, L.A., Pauletti, V., Deschamps, C., Santos, B.B., Sass, A.L. 2016. Adubação nitrogenada no rendimento da camomila [Chamomilla recutita (L.) Rauschert]. Revista Brasileira de Plantas Medicinais 18: 773-778.

Salamon, I. 2007. Effect of the internal and external factors on yield and qualitative-quantitative characteristics of chamomile essential oil. Acta Horticulturae 749: 45-64.

Santos, B.B., Pauletti, V., Roza, L.A., Silva, R.W. 2015. Aplicação de potássio na produção de camomila 
(Chamomilla recutita). Scientia Agraria 16: 22-32.

Singh, O., Khanam, Z., Misra, N., Srivastava, M.K. 2011. Chamomile (Matricaria chamomilla L.): An overview. Pharmacognosy Reviews 5: 82-95.

Streck, E.V., Kämpf, N., Dalmolin, R.S.D., Klamt, E., Nascimento, P.C., Giasson, E., Pinto, L.F.S. 2008. Solos do Rio Grande do Sul. EMATER/RS-ASCAR, Porto Alegre, Brazil. 222 p.

Streck, N.A. 2002. A generalized nonlinear air temperature response function for node appearance in muskmelon (Cucumis melo L.). Revista Brasileira de Agrometeorologia 10: 105-111.

Streck, N.A., Paula, G.M., Oliveira, F.B., Schwantes, A.P., Menezes, N.L. 2009. Improving node number simulation in soybean. Pesquisa Agropecuária Brasileira 44: 661-668.

Streck, N.A., Tibola, T., Lago, I., Buriol, G.A., Heldwein, A.B., Schneider, F.M., Zago, V. 2005. Estimativa do plastocrono em meloeiro (Cucumis melo L.) cultivado em estufa plástica em diferentes épocas do ano. Ciência Rural 35: 1275-1280.

Sváb, J., El-Din-Awaad, T., Fahmy, T. 1967. The influence of highly different ecological effects on the volatile oil content and composition in the chamomile. Herba Hungárica 6: 177-188.

Von Hertwig, I.F.V. 1991. Plantas aromáticas e medicinais: plantio, colheita, secagem, comercialização. Ícone, São Paulo, Brazil. 414 p.

WHO. World Health Organization. 2011. The world medicines situation 2011. Traditional medicines: global situation, issues and challenges. WHO, Geneva, Switzerland. $12 \mathrm{p}$.

Conflict of Interest Statement: The authors declare that the research was conducted in the absence of any commercial or financial relationships that could be construed as a potential conflict of interest.

All the contents of this journal, except where otherwise noted, is licensed under a Creative Commons Attribution License attribuition-type BY. 